Vanja Korać,

Matematički institut SANU

UDK 621.39

\title{
MOBILNI E-COMMERCE
}

\begin{abstract}
ABSTRAKT
Korisnici mobilnih uređaja po svemu sudeći već zahtevaju pristup m-commerce servisima. Zato treba postojeće tehnologije proučiti da bi se došlo do zaključka da li bi se nepromenjene mogle koristiti u svrhu m-commerce ili bi nešto moralo da se prilagodi mobilnom okruženju. Ovaj rad prikazuje pogled na remek delo mobilne trgovine kao fenomena današnjice. On je predstavljen kao opšti koncept koji pokriva bilo kakvu poslovnu transakciju koja se obavlja elektronski između najmanje dva stranke od koje je bar jedna „mobilna“. Samim tim ta strana mora da koristi medijum bežičnog prenosa makar to bio i prvi kontakt u komunikaciji te dve stane. M-commerce servisi trebalo bi da integrišu različite tipove informacija $i$ da obezbede transakcijama brzinu, bezbednost i privatnost.
\end{abstract}

KLJUČne ReČI: Mobilni telefon, RaČunar, trgovina, E-trgovina, Bezbednost, elektronske KOMUNIKACIJE, BEŽIČNE KOMUNIKACIJE

\section{UVOD}

Mobilno poslovanje je poslovanje uz upotrebu najnovije informacione i mobilne tehnologije, bilo gde i bilo kada. Da bismo razumeli šta je mobilno poslovanje moramo da krenemo od početka tj. da objasnimo šta je to e-commerce, koji su njegovi tipovi i modeli koji se tu pojavljuju, jer on, ustvari, i predstavlja bazu m-commerce-a. Sada bih izneo i neke definicije m-commerce-a koje se javljaju u literaturi mada su one manje više slične. Jedna od takvih definicija je i ta da mobilno poslovanje predstavlja Internet + Wireless + E-Business $=M$ Business (Kalakota i Robinson). To su u suštini mobilne transakcije. Mobilna Transakcija je svaka transakcija novčanih vrednosti koja se obavlja preko mobilne mreze. (Durlacher Research).

Jedna druga defiinicija mobilnog tipa biznisa glasi : „Svaka transakcija povezana sa proizvodima i uslugama, koju obavi prodavac ili kupac uz upotrebu mobilnog telefona ili organizera tj. PDA uređaja, preko mobilne mreže (interneta) predstavlja mobilno poslovanje“ (McGuire).

Forrester definiše mobilno poslovanje kao „upotrebu mobilnih ručnih uređaja za komunikaciju, međusobno povezivanje i transakcije preko brzih veza preko interneta."

Mobilno poslovanje je poslovanje uz upotrebu 
najnovije informacione i mobilne tehnologije, bilo gde i bilo kada. Da bismo pravilno razumeli kako ceo taj sistem funkcioniše ja ću da priču počnem od polazne osnove m-commerce-a.

\section{E-COMMERCE KAO PREDUSLOV M-COMMERCE}

E-commerce predstavlja jedan moderan pristup biznisu. Podrazumeva korišćenje Interneta i njegovih servisa, npr. www, za ostvarivanje transakcija. Predstavlja digitalno omogućene transakcije između organizacije i pojedinaca ili međusobno organizacija. Bitno je da su sve transakcije zasnovane na digitalnoj tehnologiji i da one zapravo predstavljaju razmenu vrednosti i novca $\mathrm{u}$ zamenu za servise, proizvode i informacije. Glavne karakteristike e-commerce su sledeće :

1. Sveprisutnost - zbog ekspanzije tehnoloških dostignuća, oprema koja je potrebna da bi se ostvarila e-commerce razmena, svuda je prisutna: u školama, u kući, na poslu, na mobilnim uređajima.

2. Globalna dostupnost - granice više ne postoje, transakcije se mogu obaviti bilo gde u svetu, daljina više nije prepreka.

3. Univerzalni standardi - Internet standardi.

4. Informaciono bogatstvo - mogućnost korišćenja i prenosa teksta, video sadržaja, audio materijala itd.

5. Interaktivnost - tehnologija koja omogućava interakciju sa korisnikom.

6. Informaciona gustina - podrazumeva opadanje informacionh troškova, a rast kvaliteta.

7. Personalizacija - tehnologija koja omogućava da se personalne poruke šalju individualno ili grupno.

Da se ovde radio o izuzetno snažnom tipu biznisa, govori i činjenica o tome koje su sve discipline uključene u e-commerce :

1. Sociologija,

2. Informatika,

3. Menadžment,

4. Informacioni sistemi,
5. Ekonomija,
6. Marketing,
7. Menadžment,
8. Finansije.

\subsection{OBLICI E-Commerce-a}

Oblike e-commerce-a razlikujemo prema odnosu na tržište i odnosu na tehnologiju.

Prema odnosu na tržište :

B2C - business to consumer,

B2B - business to business,

C2C - consumer to consumer.

Prema tehnologiji :

P2P-peer to peer,

M-commerc.

\subsubsection{B2C (business to consumer) model}

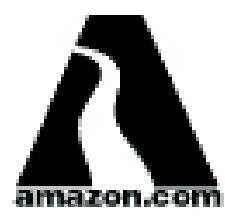

Najčešće diskutovani oblik. On-line preduzeća teže da direktno pristupe individualnim potrošačima. Potrošači u USA su potrošili \$65 milijardi u 2001. Jedan od predstavnika je Amazon.com . Oblici B2C modela:

Portal - pruža snažan alat za pretraživanje, plus integrisani paket sadržaja i servisa. Po pravilu koristi kombinovani model prihoda - pretplata, prihod od reklamiranja, i provizija po transakciji. Razlikujemo opšti i specijalizovani (vortal).

E-prodaja - on-line verzija tradicionalne trgovine na malo, obuhvata :

- virtualne trgovine (on-line prodavnice),

- klik i zidane e-trgovine (on-line distribucione kanale kompanija koje imaju istovremeno i fizičke prodavnice),

- kataloške trgovine (on-line verzije direktnih mail kataloga),

- on-line trgovinske centre (on-line verzije trgovinskih centara),

- direktna prodaja proizvođača preko Web-a. 
Provajderi sadržaja - predstavaljaju kompanije koje pružaju usluge informacija i kompanije koje se bave uslugama zabave, nude digitalne sadržaje preko Web-a. Od modela prihoda tipično je korišćenje reklama, pretplata, ili model prihoda na osnovu provizije preko partnera.

Transakcioni brokeri - predstavljaju kompanije koje vrše procesiranje on-line prodajnih transakcija. Tipično je korišćenje modela prihoda tipa transakcionih provizija.

Kreatori tržišta - Internet tehnologija koristi se za kreiranje tržišta na kome se susreću kupci i prodavci. Po pravilu se koristi model prihoda zasnovan na transakcionim provizijama.

Provajderi usluga - on-line ponuda servisa.

Provajderi okupljanja - obezbeđuju on-line okupljanje pojedinaca sličnih preokupacija, u cilju povezivanja i razmene informacija. Prihod se ostvaruje kroz provizije usmeravanja, reklamiranje ili pretplatu.

\subsubsection{B2B (business to business) model}

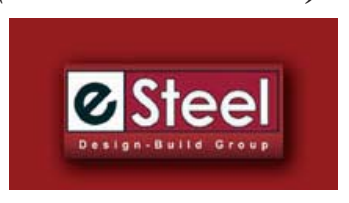

Business to business je najveći oblik ecommerce sa $\$ 800$ milijardi transakcija u 2002. godini. Primarno obuhvata razmenu između preduzeća. Preduzeća se orijentišu na prodaju drugim preduzećima (usluge, proizvodi informacije). Razvijaju se i drugi modeli :

1. B2B Hub -takođe poznat kao tržište-razme$n a$, elektronsko tržište gde dobavljači i trgovci na veliko mogu da obave transakcije. Mogu biti opšti (horizontalno tržište) ili specijalizovani (vertikalno tržište).

2. E-distributeri - ostvaruju direktno snabdevanje proizvodima induvidualnih poslovnih jedinica.

3. B2B provajderi servisa- prodaja poslovnih servisa drugim kompanijama.

4. B2B posrednici - povezuju različita poslovanja, a naplatu usluga vrše po transakciji ili na osnovu provizija za usluge.

5. Infomediari - nalaženje i preprodaja poslovnih informacija.

Osobina ovog modela je da skraćuje proizvodni ciklus, ,just-in-time“ upravljanje zalihama. Jedan od predstavnika je eSteel.com.

\subsubsection{C2C (consumer to consumer) model}

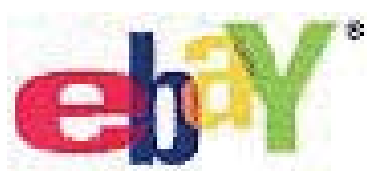

Omogućava potrošačima direktnu međusobnu trgovinu. Procena vrednosti ovog tržišta je oko 15 milijardi \$ u 2004. godini. Ovaj model se ostvaruje na sledeći način. Pojedinac priprema proizvod za tržište, stavlja proizvode na aukciju ili prodaju, oslanja se na tržišne posrednike (on-line markete), koji obezbeđuju kataloge, pretraživače i servise za kompletiranje transakcija. Jedan od predstavnika je eBay.com.

\subsubsection{P2P (peer to peer) model}

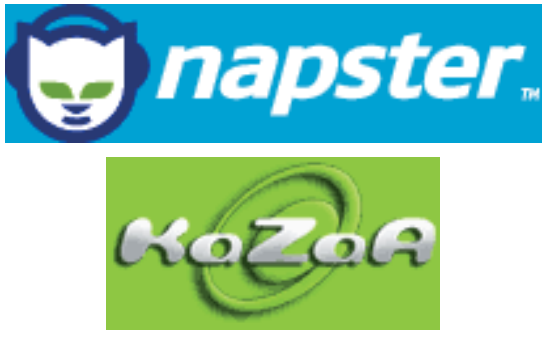

Omogućava korisnicima Interneta razmenu fajlova i drugih računarskih resursa Primer: Napster, Kazaa, Gnutella. Kazaa je danas vodeća P2P softverska mreža, mada i dalje pod udarom zakona o zaštiti autorskih prava.

\subsubsection{M-COMMERCE model}

Omogućava korisnicima bežičnih digitalnih uređaja da vrše transakcije na Web-u. Za konekciju se koriste tzv. PDA uređaji (Personal Digital Assistant) ili smart moblni telefoni. U ovom radu se upravo opisuje ovaj tip modela e-commerce biznisa. 


\section{M-COMMERCE MODEL}

U širem smislu M-commerce (eng. Mobile commerce) predstavlja svaku transakciju realizovanu preko mobilne telekomunikacione mreže, dok u užem smislu to predstavlja transakciju novčane vrednosti preko mobilne telekomunikacione mreže. U skladu sa ovom definicijom, $m$ commerce predstavlja podskup svih e-commerce transakcija, kako u B2C (business-to-consumer), tako i u B2B (business-to-business) segmentu.

Uključuje, kombinovanje govora, podataka, audio i video sadržaja na jednom bežičnom uređaju. Bežični digitalni uređaji omogućavaju transakcije na Web-u. Za konekciju se koriste tzv. PDA uređaji (Personal Digital Assistant) ili mobilni telefoni . Najčešće se koriste u Japanu i Evropi.

Za mnoge ljude širom sveta, mobilni telefoni predstavljaju prvu tačku pristupa Intenetu, samim tim i e-commerce sistemima. Danas, većina istraživanja

m-commerce sistemima predviđa uspešnu budućnost, sa perspektivom da ovaj model elektronske trgovine postane i dominantan na pojedinim nacionalnim i regionalnim tržištima. Jedan od predstavnika je Amazon.com, koji je prilagodio biznis aplikacije bežičnoj tehnologiji.

M-commerce aplikacije omogućavaju primenu bežičnih mobilnih uređaja za kupovinu različitih roba u usluga, pozorišnih i prevoznih karata, knjiga, realizaciju bankovnih transakcija, pristup plaćenim sadržajima i informacijama (repertoar bioskopa, red vožnje, vremenska prognoza, kursna lista, izveštaji sa berzi...). Sve ove opcije su prisutne i u e-commerce aplikacijama i sistemima. Prednosti m-commerce sistema, u odnosu na klasične $\boldsymbol{e}$-commerce sisteme su višestruke, ali one ne mogu biti u potpunosti iskorišćene dok se ne otkloni niz nedostataka i nesavršenosti. Kao najvažniji nedostaci $m$-commerce aplikacija izdvajaju se, pitanje autentifikacije, sigurnosti i privatnosti.

Kao poseban problem snažnom razvoju $m$ - commerce sistema konkretno u našoj zemlji nameće se niži nivo razvijenosti mobilnih telekomunikaciionih mreža. Postojeća, druga generacija mobilnih telekomunikacionh mreža u SCG, nije dovoljna za puni napredak mobilne elektronske trgovine.

\subsection{Pokretači razvoja m-commerce}

Preduslov razvoja mobilne elektronske trgovine je, bez sumnje, napredak i uvođenje novih tehnologija mobilnih telekomunikacija. Praktično, postojeće tehnologije su i jedino značajno ograničenje bržeg razvoja $m$-commerce tehnologija i sistema u našoj zemlji . U nekoliko narednih godina, očekuje se prelazak sa današnje druge generacije mobilnih telekomunikacija (pre svega GSM 900 i GSM 1800) na treću generaciju mreža i uređaja mobilne telefonije $(3 \mathrm{G})$. Treća generacija mobilnih telekomunikacija će stvoriti uslove za potpunu ekspanziju mobilne elektronske trgovine. Međutim, već sada se može izdvojiti više pokretača budućeg razvoja $m$-commerce-a :

- Masovno tržište mobilne telefonije ;

- Nagli razvoj Interneta i elektronske trgovine;

- Usavršavanje opreme i uređaja za mobilnu telefoniju ;

- Novi principi tarifiranja servisa ;

- Uspeh u podeli licenci za UMTS (3G).

Uvećini zemalja Evropske Unije, iskorišćenost mobilne telefonije je već uveliko prešla 50 procenta. U SCG, trenutno ima između 2 i 11.5 miliona mobilnih pretplatnika u zavisnosti od izvora procene. Kako su procene o broju mobilnih pretplatnika različite, tako su prisutna i suprotna mišljenja o dinamici povećanja njihovog broja u narednom periodu.

Drugi značajan pokretač mobilne trgovine je nagli razvoj Interneta i elektronske trgovine. Sa preko 50 miliona korisnika u prvih pet godina komercijalne primene, Internet je postao najbrže prihvaćen medijum masovne komunikacije $u$ istoriji. Koliko je brzina širenja Interneta velika, možda najbolje odslikava poređenje sa telefoni- 
jom kojoj je trebalo 70 godina, i televizijom kojoj je trebalo 15 godina da pređe put do 50 miliona korisnika.

S' obzirom da je većina svetskih proizvođača opreme i mobilnih telefona osvojila proizvodnju aparata koji su dostigli tehnološki limit druge generacije mobilnih telekomunikacionih mreža, $\mathrm{u}$ fokusu njihovog rada, $\mathrm{u}$ ovom trenutku, nalazi se oprema treće generacije i komplementarne tehnologije. Kompanije koje su već obavile uspešna testiranja $3 \mathrm{G}$ telefona (Nokia, Ericsson), spremaju i komercijalizaciju 3G mreža (NEC za potrebe BT-ove filijale Manx Telecom). Paralelno sa radom na $3 \mathrm{G}$ proizvodima, većina kompanija posebnu pažnju posvećuje razvoju Bluetooth opreme i uređaja. U našoj zemlji, dominantna tehnologija je i dalje GSM (2G).

Sa uvođenjem GPRS (2G++) tehnologije kakve su uveli (Mobtel i Telekom), dolazi i do promene sistema tarifiranja, kao preduslova za potpuni razvoj m-commerce sistema i servisa. GPRS promoviše tzv. ,always on“ model tarifiranja, koji je jedini relevantan, kada je mobilni Internet u pitanju. Ovaj model favorizuju, pre svih, operateri mobilne telefonije, koji na ovaj način ostvaruju veće predvidljivije prihode. Na kraju, dolazimo i do tehnološki odlučujućeg faktora razvoja mobilne trgovine- UMTS mobilnih mreža treće generacije. UMTS tehnologija (Universal Mobile Telecommunication System - Jedinstveni Mobilni Telekomunikacini Sistem) u punoj meri obezbeđuje kvalitetan prenos video signala preko mobilne telekomunikacione mreže, sa prognozom brzine prenosa podataka do $384 \mathrm{kbps}$. 3G objedinjuje dvije moćne snage: širokopojasne radiokomunikacije i usluge temeljene na IP-u. Wideband Code Division Multiple Access (WCDMA) je način širokopojasnog višestrukog radio pristupa, koji omogućuje mnogo veće brzine prijenosa podataka od onih koje nam pružaju danas (GPRS i EDGE, podaci se prenose brzinom od $46 \mathrm{kbps}$, odnosno $220 \mathrm{kbps}$ ) primjenjivani načini radioprijenosa: do 2Mbit/s uz vrlo efikasno korišćenje radio-spektra. Uz pomoć WCDMA tehnologiju biće moguće paralelno korišćenje nekoliko govornih, video i usluga prenosa podataka $u$ isto vreme. Da bi 3G postao naša svakodnevica, istraživači su radili na brojnim područjima. 3G omogućuje bežični (radio) pristup velikim brzinama i usluge utemeljene na Internet protokolu (IP) integrišući ih u jedinstveno, telekomunikacijsko okruženje. Korak prema IP je presudan. IP se temelji na paketnom prenosu, što jednostavno znači da korisnici mogu imati stalnu vezu (“on line”), a plaćati samo stvarnu količinu primljenih ili poslatih informacija. IP protokol pruža niz pogodnosti te čini pristup mnogo bržim: učitavanje datoteka se obavlja u svega nekoliko sekundi, a na mrežu kompanije se možete priključiti samo jednim pritiskom miša.

Ukupna ulaganja u opremu i razvoj servisa za 3G mreže u Zapadnoj Evropi dostiže neverovatnih 500 milijadri eura, naravno uz poteškoće i neminovne zastoje. Ipak, velika potražnja za $3 \mathrm{G}$ licencama se može jedino objasniti time što će nova generacija mobilne telefonije doneti velike prihode svojim vlasnicima (operatorima). Jedan od činilaca (verovatnog) uspeha je i m-commerce, čiju vrednost do kraja 2005. godine u Evropi, procenjuju na više od 100 milijardi dolara ${ }^{1}$. Nažalost u našoj zemlji predstoji tek podela $3 \mathrm{G}$ licenci. Naravno, to nije sve, već se pojavljuje i novi standard. Dvadeset šest operatora mobilne telefonije i proizvođača telekonunikacione opreme iz Azije SAD i Evrope potpisalo je nedavno sporazum o razvoju novog standarda za mobilnu telefoniju treće generacije (3G). Radi se o standardu „Su-

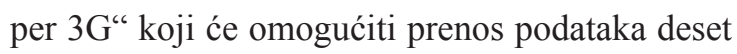
puta većom brzinom od postojećeg standarda $3 \mathrm{G}$. Novi standard će na primer omogućiti „,skoro trenutni pristup video visoke rezolucije" navodi se u saopštenju objavljenom nakon potpisivanja sporazuma. Očekuje se da će prva faza razvoja standarda Super 3G biti završena do 2009. godine.

Potpisnici sporazuma su odlučili da ne grado potpuno novu mrežu nego da unaprede postojeću infrastrukturu. Razlog za tu za tu odluku najeverovatnije leži u činjenici da su u postojeće $3 \mathrm{G}$ mreže

1. Procena konsultantske firme MCKinsey. 
uložena ogromna finansijska sredstva, što je njihove vlasnike umalo dovelo do bankrotstva. Samo NTTDoCoMo, primera radi, uložiće oko milijardu dolara u reorganizaciju svoje $3 \mathrm{G}$ mreže i njeno usklađivanje sa stadrardom Super 3G.

Među potpisnicima sporazuma su između ostalih, kompanije NTT DoCoMo, Vodafone group, Cingular Wireless, Chine Mobile Communication, NEC, Alcatel i Siemens.

\subsection{Stvaranje uslova za ostvarenje m-com-} merce

Pre nego što $m$-commerce zaživi, potrebna je čvrsta osnova koja se sastoji od 7 elemenata:

1. Ponuda interesantnih aplikacija.

2. Olakšano korišćenje, tako da je navigacija laka i logična. Na primer, aplikacije restorana, koje rangiraju restorane po popularnosti, su korisnički privlačnije nego rangiranje po abecednom redu.

3. Aplikacija mora biti stabilna i obezbeđena.

4. Neophodne su packet-switched mreže.

5. Mobilni uređaji moraju biti u koloru, sadržati grafiku i što više redova teksta.

6. Obezbeđenje jednostavnog pristupa servisu koji mora da ima mogućnosti opsluživanja više konekcija odjednom.

7. Fokusiranje na urbanu populaciju. Obično je urabanija populacija spremnija za naprednije servise, jer ih duže i češće upotrebljava. Mlađa populacija i tinejdžeri bi bili ciljna grupa.

\subsection{M-commerce servisi}

Pre svega mora se uzeti u obzir cena uvođenja mobilnog poslovanja. Ona može široko varirati u zavisnosti od toga kako je mobilno rešenje implementirano, kolika je cena licenciranog softvera i slično. Troškovi se generalno mogu podeliti na:

- Hardver uključuje mobilne terminale (telefone, PDA uređaje...), servere, WLAN mreže i drugo.

- Softver, razvoj i integracija uključuje licencu za platforme, razvojni alat, troškove razvoja i integracije sa back-end sistemima i postojećim WEB aplikacijama.
Kada se donese konačna odluka o prelasku na mobilno poslovanje, veliki izazov predstavlja definisanje uspešne strategije za rad u mobilnom okruženju. Uspešno poslovanje u mobilnom svetu zahteva od kompanija, upravo, da razumeju razlike između mobilnog Interneta i Interneta i da prihvate izazove koje pred njih stavljaju mobilne tehnologije. Tek tada se može govoriti o uspehu u svetu mobilnog poslovanja.

Prema istraživanju ${ }^{2}, 80$ procenata korisnika Interneta koristilo je ovaj medijum za kupovinu ili informisanje o konkretnim proizvodima. Istraživanje je od značaja upravo zbog uključivanja i onih Internet korisnika, koji nisu ostvarili prave on-line kupovine, već su Internet koristili za sakupljanje inforamacija i upoređivanje karakteristika i cena konkurentskih proizvoda. Na sličan način funkcioniše i m-commerce. M-commerce transakcije ne moraju biti samo on-line kupovine (slika 1.). Praktično, m-commerce servisi koriste i “clickand-mortar" poslovni model. Click-and-mortar model, treba da približi svoje poslovnice kako bi bile što pristupačnije korisnicima za isporuku.

Kada e-kompanija izgradi svoje poslovnice blizu kupaca i kada su isporuke od skladišta do krajnjeg korisnika ekonomične, onda kompanija može da stvori uslove da mušterija sama preuzme robu (na primer, kupac naruči proizvod on-line i preuzme ga u najbližoj prodavnici te firme). Kupci mogu takođe da koriste web-sajtove da bi našli informacije o proizvodima, a zatim u najbližoj prodavnici ili kod dilera preuzeli robu. Ovaj model je praktičan i za povratni proces (vraćanje robe, reklamacije i slično).

Evo primera, kako bi se odvijala kupovina avionske karte. Korisnik može preko mobilnog telefona ili PDA uređaja, izabrati željeni avionski let i kupiti kartu, čak i uz mogućnost real-time plaćanja, ali ipak mora otići do agencije ili aerodroma da je fižički preuzme.

M-commerce servisi su u osnovi "short-time" servisi, i to iz više razloga.

Prvo, mobilni telefoni i uređaji za mobilnu ko-

2. Prema istraživanju Jupiter Research-a. 


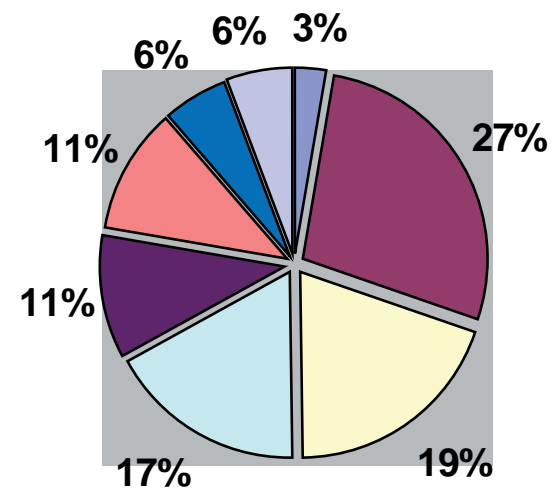

\begin{tabular}{|ll|}
\hline$\square$ Rezervacija karata & $\square$ Vesti \\
$\square$ Vreme & $\square$ Transportne informacije \\
$\square$ Bankarstvo & $\square$ Kupovina \\
$\square$ Horoskop & $\square$ Zabava \\
\hline
\end{tabular}

S1. 1. :Učešće usluga u m-commerce

munikaciju imaju više tehnoloških ograničenja u odnosu na osnovno sredstvo e-commerce servisa a to je personalni računar (ograničenja u manipulaciji, autorizacija, sigurnost i privatnost).

Drugo, mobilni telefoni su uvek kod svojih vlasnika, bez obzira gde se oni nalaze. Zbog toga se nameću kao najbolji izbor u slučaju potrebe trenutne akcije, koja je uslovljena. Uslovno rečeno, sve ozbiljnije on-line kupovine će se i dalje (još neko vreme) ostvarivati uz komfor personalnog računara na poslu ili kod kuće.

Treće, $m$-commerce servise možemo podeliti u 4 generacijske grupe :

1. Prvu generaciju (1999. godina) čine osnovni servisi (glas, organizatori)

2. Drugu grupu (2000. godina) predstavljaju tzv. informacioni servisi, kao što su e-mail, vremenska prognoza, turističke inforamacije, yellow pages.

3. Treću generaciju servisa (2001. godine) čine tzv. transakcioni servisi- turističke rezervacije, bankarske transakcije, on-line aukcije.

4. Četvrta generacija servisa se ostvaruju sa razvojem $3 \mathrm{G}$ mreža. Upravo $3 \mathrm{G}$ tehnologija određuju mogućnosti 4. generacije m-commerce servisa, koja uključuje multimediju, video konferencije i on-line igre.

Iz korisničkog ugla m-commerce servise možemo podeliti na:

- Bankarske usluge;

- Berzanke usluge;

- On-line kupovinu (šoping) i

- servise sadržaja (novosti, vremenska prognoza, horoskop).

\subsection{M-commerce -mobilno bankarstvo}

Kada je reč o mobilnom bankarstvu, hteo bih ukratko da objasnim kako se ono ostvaruje. Naime, sada su finansijske institucije u mogućnosti da ponude različite vrste usluga kao što su bankarske, brokerske, berzanske, usluge osiguranja, i to preko mobilnih telefona, ili personalnih digitalnih asistenata (PDA). Na taj način ove institucije istovremeno povećavaju lojalnost svojih klijenata, kao i produktivnost svojih zaposlenih.

Lojalnost korisnika je važnija od isključivog povratka investicija. Naravno, aspekt lojalnosti korisnika je veoma važan, ali zaposleni takođe mogu imati koristi od mobilnih servisa, i upravo to dovodi do povećanja produktivnosti i efikas- 
nosti. Na primer, kada Investiciona banka vrši istraživanja, ona može imati dodatne koristi, ako najnovije informacije distrubuira do svojih zaposlenih, u trenutku njihovog nastajanja.

Pošto mobilni Internet omogućava korisnicima da pristupe finansijskim isntitucijama sa bilo kog mesta i u bilo koje vreme (postupak sledi u daljem izlaganju), kompanije koje se bave pružanjem finansijskih usluga treba da na mobilne servise gledaju kao na dar, a ne da brinu o tome kako će im se povratiti uložene investicije. Personalizacija je ključ za lojalnost korisnika, čime se uspostavljaju jake veze sa korisnicima koji ne zavise od određene lokacije. Razvijajući neke drugačije i naprednije servise koji se ne mogu naći bilo gde na tržištu, privlače se korisnici i povećava njihova lojalnost. Na taj način se može postati lider na tržištu. Broj finansijskih servisa u velikoj meri zavisi od raspoložive mobilne platforme na kojoj će se izvršavati. $U$ današnje vreme imamo različite vrste finansijskih servisa i možemo ih podeliti na:

1. bankarske,

2. brokerske,

3. servise investicionog bankarstva,

4. i druge finansijske servise.

\subsubsection{Bankarski servisi}

Skoro sve veće banke su uvele ili planiraju da uvedu servise mobilnog bankarstva. Dok je većina starijih aplikacija realizovana putem SMS-a, dvosmerni komunikacioni protokol (većina današnjih aplikacija) bazirana je na WAP standardu ${ }^{3}$. WAP omogućava mobilnim uređajima da komuniciraju preko Interneta jednostavnim unošenjem adrese kojoj žele da pristupe. Raniji servisi bili su tipično informaciono-bazirani. Korisnici su mogli da putem svog mobilnog uređaja proveravaju stanje na računu, stanje na kreditnim karticama ili da dobiju neke osnovne finansijske informacije. U današnje vreme banke počinju da objedinjuju mogućnosti transakcije u svojim servisima. Od ovih servisa najčešće se koriste plaćanje računa, prenos sredstava ili aplikacije kreditiranja.

3. Wireless Aplicaton Protokol

\subsubsection{Brokeri}

Brokerske kuće su hitno, neke od svojih servisa prebacile i na mobilni Internet. Nezavisnost od vremena i lokacije pristupa mobilnih brokerskih servisa predstavljaju karakteristike, koje su veoma atraktivne za one korisnike koji često trguju. Kao dopunu, mobilni brokerski servisi nude svojim korisnicima da hitro reaguju na promene u uslovima tržišta. Brokerske kuće nisu u mogućnosti (za sada ) da u potpunosti ponude sigurne aplikacije. Iz tog razloga one su se fokusirale na informaciono-bazirane aplikacije, kao što su praćenje vesti, pregled vrednosti akcija u realnom vremenu i proveru računa.

\subsubsection{Investiciono bankarstvo}

Investicione banke su uvidele potencijal koji donosi m-commerce kako za povećanje produktivnosti njihovih zaposlenih, tako i za dodavanje novih servisa za institucije i privatne klijente. Sa aspekta prodaje i trgovine, investicione banke nude svojim klijentima "Just in case" mobilne aplikacije koje će u svako doba biti povezane sa tržištem. Važne vesti, promene cena, različite analize mogu biti isporučene korisnicima odmah po njihovom nastajanju, bez obzira na kojoj se oni lokaciji nalazili. Sa aspekta akcionarskog invesitiranja i iz oblasti konsaltinga, aplikacije mobilnog poslovanja obezbeđuju kompletnu finansijsku pomoć. Iz oblasti konsaltinga one omogućuju alate za podršku u odlučivanju, pomoću kojih donosioci odluka mogu da dele svoje mišljenje sa klijentima.

\subsubsection{Drugi finansijski servisi}

Dok su banke i brokerske kuće bile prve koje su svoje servise ponudile u bežičnom svetu, druge finansijske ustanove, kao što su osiguravajuće kompanije, zajmodavci i hipotekarske ustanove, savetodavne institucije, kao i kreditne ustanove, bi trebalo da u skorije vreme razviju aplikacije mobilnog poslovanja. Na primer, putnik na aerodromu može da primi poruku koja ga obaveštava o paketima osiguranja koje može da dobije, 
ekspert za pozajmice može takođe preko mobilnog uređaja da prikaže različite opcije pozajmica svojim klijentima.

\subsection{M-COMMERCE U POSLOVNIM SISTEMIMA}

Različiti poslovni procesi mogu biti unapređeni i realizovani integracijom mobilnih tehnologija. Uvođenjem mobilnih uređaja kao izbora interfejsa, omogućen je lakši pristup informacijama i operacijama unosa podataka, povećana je dostupnost zaposlenih u skoro svakom trenutku, u slučajevima donošenja odluka i slično. Poslovni procesi postaju dinamičniji i praktično , ,realtime“. M-commerce mora biti integrisan sa drugim korisničkim servisima. Dobra m-commerce strategija ne znači da ona treba da bude izolovana od drugih korisničkih kanala u organizaciju. Kompanije koje ne integrišu svoje tradicionalne Web strategije i Brick and Mortal modele poslovanja samo zbunjuju i udaljuju svoje korisnike. $M$-commerce mora biti inkorporiran u strategiju organizacije tako da dopunjuje i da bude dopunjavan od strane drugih servisa. Kompanija mora da ima takođe i Rollout strategiju ${ }^{4}$. Pre nego što pusti svoj sistem u rad, kompanija bi prvo trebalo da ga isproba na nekoj lokaciji u kojoj će se on koristiti u manjoj meri. Tek posle rada na palmsourcenekom probnom tržištu, aplikacija bi trebalo da se "roluje" odnosno pusti u rad na ključno područje.

Danas postoji više oblasti eBusiness-a, gde bežične tehnologije imaju značajan uticaj i stvaraju novu ,vrednost“"

- Integracija lanca snabdevanja,

- Telemetrija,

- Upravljanje transposrtnom flotom,

- Upravljanje odnosima sa korisnicima,

- Automatizacija prodaje,

- WASP ${ }^{5}$ i druge.
Od posebnog značaja je uvođenje mobilnih telekomunikacija u zadatke i procese upravljanja odnosima sa korisnicima. U današnje vreme najznačajnije softverske kompanije u ovoj oblasti (SAP, Siebel, Oracle, Onyx, Remedy) praktična rešenja su već ponudili.

\subsection{OSTVARIVANJE FINANSIJSKIH I DRUGIH MOBILNIH TRANSAKCIJA}

\subsubsection{Mobilni uređaji}

To su ustvari klijentski uređaji Palm, iPaq, pejdžeri, Smart telefoni, WAP telefoni. Oni u sebi sadrže i operativni sistem. Operativni sistem je softverski paket koji upravlja osnovnim operacijama računara, operativni sistemi razvijeni za mobilne uređaje su:

a. Windows CE: verzija microsoftovog windows-a . Instaliran je na mnogim PDA uređajima

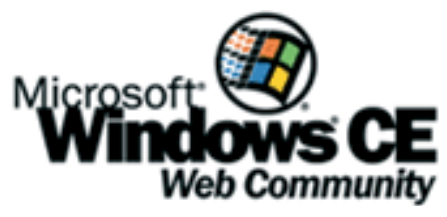

b. Palm OS: Razvijen je od strane 3COM-a. Predstavlja najpopularniji OS za mobilne uređaje i široko je rasprostranjen na tržištu. Ima ugrađenu podršku za neke Java aplikacije.

Strategija puštanja u rad aplikacije.

5. Wireless Application Service provider

c. Linux: Veoma efikasan, ima podršku za Java aplikacije, otvoren kod i može da se instalira na većini PDA uređaja i na smart telefonima.

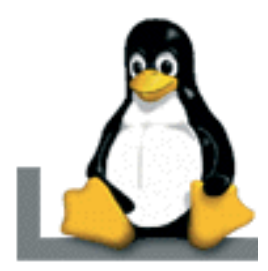




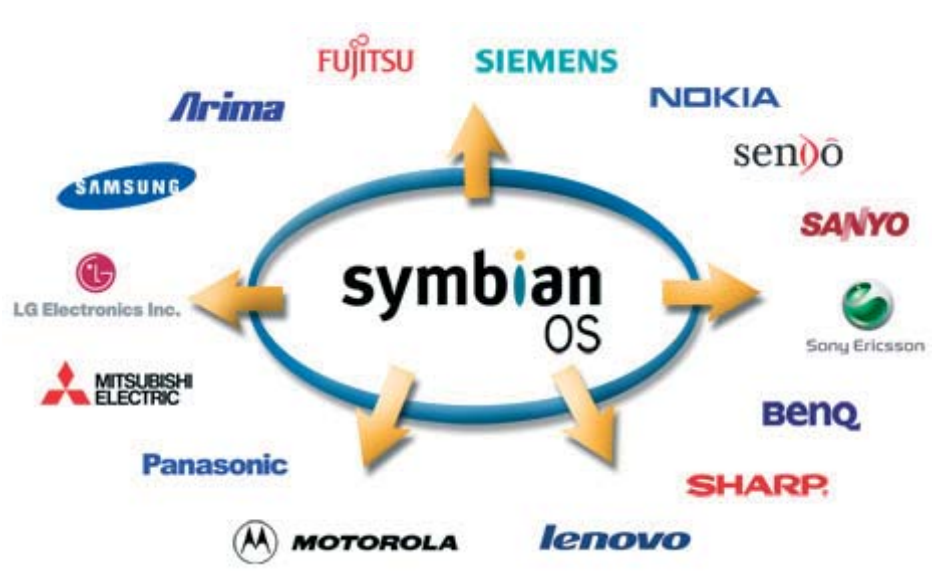

d. EPOC/Symbian : Operativni sistem razvijen za telefone Sony Ericsson, Nokia, Samsung, Siemens, Sharp i mnoge druge proizvodjače mobilnih telefona.

Svaki od mobilnih uređaja zahteva određeni način komunikacije, kao i gateway za komunikaciju sa aplikativnim serverom. Svaki uređaj ima različite karakteristike :

Veličina ekrana prilagođena je različitim vrstama prikaza podataka ;

Tastatura treba da generiše različite sisteme navigacije sa aplikacijom.

Aplikativni server stoga ima značajnu ulogu jer mora da razvrstava ove uređaje i da svakom šalje podatke u formatu koji će biti u skladu sa njihovim dizajnom.

\subsubsection{Povezivanje, Gateway}

Polazeći od krajnjeg korisnika, mobilni uređaj, može biti bilo koji uređaj kojim on pristupa lokalnom cell centru. Cell centar odgovara za pokrivenost određenog geografskog regiona. Kada primi podatke on ih šalje baznoj stanici. Mobilna mreža snima i identifikuje sve potrebne informacije u lokalnom registru, ukoliko je korisnik na lokalnoj geografskoj pokrivenosti. Ako nije, tada stanica pravi poziv i određuje se roaming ${ }^{1}$ poziva. Kada

1. Roaming je usluga koja omogućava korišćenje mobilnog telefona van granica zemlje, odnosno područja koje pokriva GSM operater čije se usluge koriste, na osnovu sklopljenog komercijalnog roaming ugovora sa nekim od mobilnih operatora te zemlje. Biti u roamingu znači biti van granica zemlje matičnog operatera i koristiti roaming usluge. Svi razgovori obavljeni u roamingu, podležu roaming tarifiranju. Roaming tarifa razlikuje se u zavis- se poziv inicira (slika 2.), uređaj šalje svoj identitet preko Electronic serial number-a (ESA) i mobilnog identifikacionog broja (MIN). Ove informacije su od vitalnog značaja jer preko njih gateway vrši identifikaciju korisnika. Na ovaj način aplikacioni server priprema podatke koje će kasnije poslati odgovarajućem korisniku.

Paket je kolekcija podataka pripremljena za poseban način slanja.

Postoje dva načina prenosa i to, takozvani circuit tip prenosa i paketski način prenosa podataka. Circuit je tip prenosa u kojem se uspostavlja trajna i nepromenjiva fizička veza između dva korisnika za vreme njihove konekcije. Trajanje veze identično je trajanju poziva. Paketski prenos ne zahteva otvorenu liniju između pošiljalaca i primalaca podataka. Ovaj metod omogućava da se podaci podele u veći broj paketa i da se pošalju. $\mathrm{Na}$ prijemnoj strani oni se ponovo sklapaju u celinu. Druga prednost paketnog sistema prenosa ogleda se specifičnom korišćenju određenog radio kanala, koji je zauzet samo u trenucima kada postoji realan protok podataka. Kada takvog protoka nema, veza se oslobađa i stavlja na raspolaganje drugom korisniku. To je mnogo efikasniji način korišćenja veze od rezervisanja fiksnog kanala za jednog korisnika na određeno vreme, pošto na ovaj način veći broj njih može koristiti isti kanal. Broj korisnika koji mogu simultano koristiti jedan kanal, limitirana je jedino količinom podataka koji se prenose, a njega operateri mogu lako ograničiti. Konektivnost koja zavisi od različitih mobilnih uređaja, takođe može varirati od provajdera do provajdera.

\subsubsection{Bežični srednji sloj (aplikativni sloj)}

Aplikativni sloj je centralni deo mobilnog sistema. To je mesto gde se tok podataka kontroliše, postavljaju i izvršavaju pravila. Aplikativni softver bi trebalo da bude otvoren sistem nosti od zemlje u kojoj se nalazite i operatera s kojim matična mreža ima sklopljen ugovor o komercijalnom roamingu, a koji je diktira. 


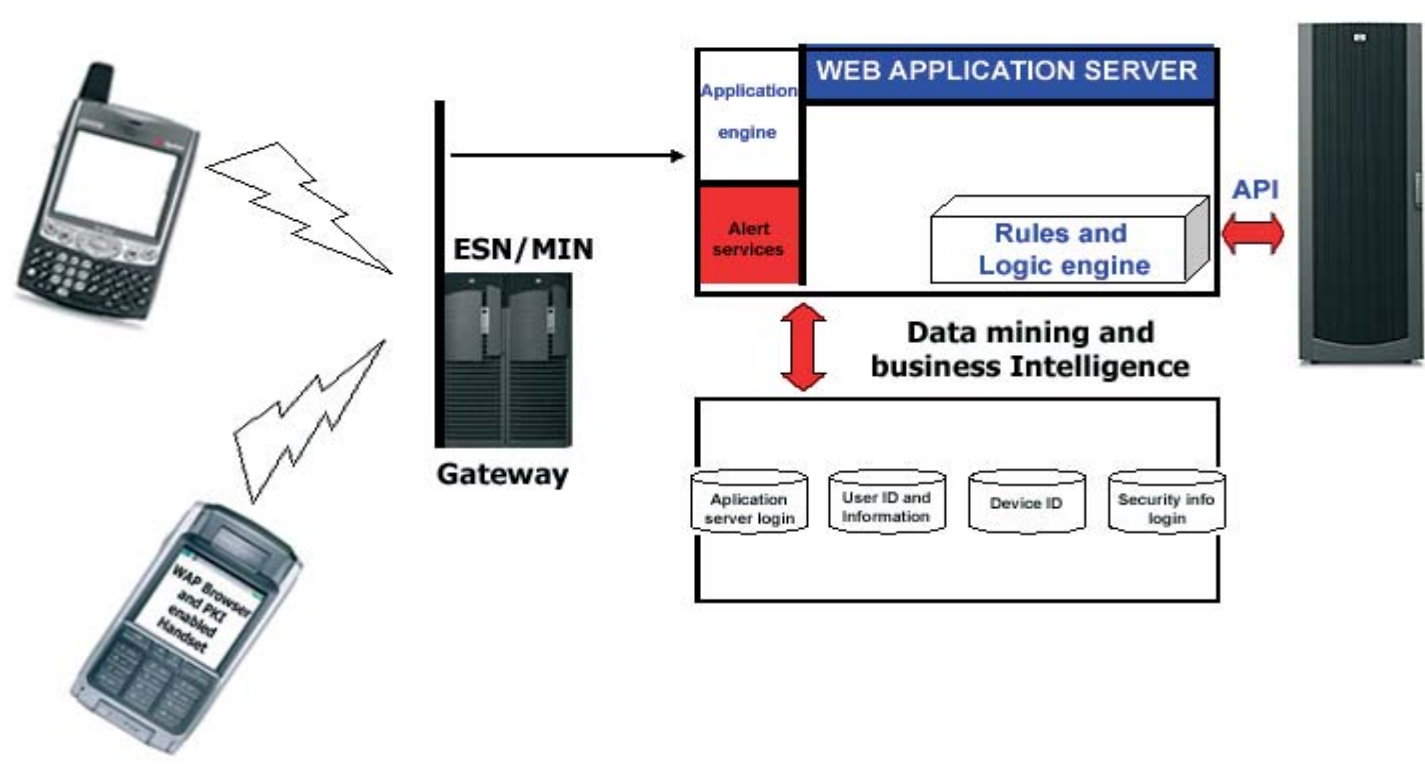

S1. 2. : Arhitektura mreže

koji lako može da uspostavi komunikaciju sa drugim sistemima. Aplikativni softver mora da poseduje sledeće karakteristike :

- Robusnost-sistem može da podržava obavljanje transakcija 24 sata sedam dana u nedelji ;

- Skalabilnost- servis je spreman da prihvati sve veći broj korisnika bez dodatnog rada na razvoju aplikacije;

- Distributivnost-omogućava da se proces veoma brzo izvšava i da korisnik u najkraće vreme dolazi do podataka uprkos većem broju slojeva kroz koje oni prolaze;

- Fleksibilnost-razdvojeni su podaci, poslovna logika, i prezentacioni sloj tako da se lako mogu dodavati nova rešenja u sistem bez potrebe za ispravkama ;

- Lak za instaliranje, konfigurisanje i dodavanje novih servisa ;

- Klijentska aplikacija mora biti laka za instalaciju;

- Lak za integraciju sa drugim serverima i back-end sistemima;

- Mora biti zaštićen od različitih vrsta upada.

Jedan od najčešćih metoda komunikacije sa back-end sistemima je XML-API alat za rad sa podacima.

\subsubsection{Transcoding}

Transcoding je proces formatiranja podataka, kojima korisnik pristupa putem svog mobilnog uređaja, upotrebom XML, XSL i DTD fajlova. Ovaj metod omogućava krajnjem korisniku da pristupi podacima bez obzira koji uređaj koristi.

Kada se sa mobilnog uređaja inicira zahtev za pristup podacima, aplikativni server prihvata zahtev i određuje sa kojeg uređaja se vrši pristup. Koristeći više logičkih procesa, aplikativni server procesira podatke u XML dokument koji može komunicirati sa back-end sistemom preko API konekcije. Rezultat je da su izvorni podaci transormisani (procesirani) upotrebom XSL style sheet $\mathrm{u}$ format odgovarajuć mobilnim uređajima. Ovaj postupak je veoma složen.

Aplikacioni server može korisititi standardne osobine mobilnih sredstava za upravljanje podacima. Ovo može doprineti lakšem razvoju aplikacije. Na nivou aplikacionog servera mogu biti uskladišteni user Id i Id mobilnog uređaja. Aplikacioni server pristupa bazi u trenutku kada primi zahtev za pristup od mobilnog uređaja. Baza priprema format podataka u zavisnosti od uređaja koji joj pristupa. Aplikacioni server takođe poredi identifikacioni broj uređaja sa korisničkim Id 
i tako vrši verifikaciju. Zatim aplikacioni server uspostavlja komunikaciju sa gateway serverom, a ovaj dalje prosleđuje podatke uređaju koji je inicirao konekciju.

\subsubsection{Pushing i puling podataka}

Pull tehnologija je tehnologija u kojoj klijent inicira komunikaciju koristeći gateway i zahtevajući podatke. Tada se podaci dovlače sa aplikacionog servera na mobilni uređaj.

U push tehnolgiji aplikacioni server ima veću kontrolu nad mobilnim uređajima. Aplikacioni server donosi odluku kada će poslati podatke mobilnom uređaju. Za push tehnologiju nije potreban prethodni zahtev klijenta.

\section{MOBILNO PLAĆANJE}

Servisi mobilnog plaćanja su još u fazi razvoja. Za sada još uvek nema najboljeg rešenja koje bi zadovoljilo većinu korisnika i koje bi se nametnulo kao standard na tržištu. Razvoj mobilnog plaćanja će se nastaviti dok se ne iskristališe jedno ili dva rešenja koja će se nametnutu kao standard na tržištu. Za sada imamo nekoliko ponuđenih rešenja.

\subsection{Rešenja koja koriste kartice}

Pokušaji mobilnog plaćanja u prvo vreme obuhvatali su standardne bankarske kreditne i debitne kartice u integraciji sa mobilnim telefonom. Postupak plaćanja je bio sledeći. Korisnici su pomoću telefona ili Interneta naručivali proizvode, preko svog mobilnog telefona primali su SMS poruku o uspešnoj narudžbini, a zatim su kompletirali transakciju tako što su ubacivali karticu u čitač i unosili šifru. Ovakva vrsta plaćanja nas dovodi do uverenja, da su ovi uređaji korisniji od običnih mobilnih telefona. Međutim, kompanije bi morale da ponude integrisano rešenje mobilnih uređaja i čitača kartica. Prednost je naravno stepen sigurnosti koji je u ovom slučaju izuzetno visok i vezan za čitača kartica.

\subsection{Rešenja koja ne koriste kartice}

Kompanije takođe nude usluge mobilnog plaćanja za koje nije potrebna upotreba smart kartica. Korisnici obavljaju transakcije tako što unose poseban broj koji se odnosi, na recimo, parking servis ili bilo kojeg drugog pružaoca usluga. Operater mobilne telefonije u ovom slučaju igra ulogu i klirinške kuće, on kreditira korisnikov unapred određen račun. Ovakve aplikacije plaćanja bez upotrebe kreditnih kartica su veoma privlačne za korisnike pošto omogućavaju klijentima i trgovcima da obavljaju transakcije upotrebom postojeće infrastrukture. Nema nikakve potrebe da pojedinac kupuje posebne uređaje ili da kompanije ulažu dodatne investicije u svoju opremu. Najvažniji nedostatak ovakvog oblika plaćanja je sigurnost. Postojeće rešenje se oslanja na sigurnost GSM mreže koja sama po sebi nije dovoljna da spreči zloupotrebe prilikom transakcija.

\subsection{Bluetooth rešenja plaćanja}

Bluetooth tehnologija omogućava uređajima da na malim razdaljinama komuniciraju pomoću brzih radio signala. Takođe, može da odigra važnu ulogu u sistemima mobilnog plaćanja. Pomoću bluetooth tehnologije korisnici mogu da obavljaju različite vrste mikro plaćanja, tako što će svoj mobilni telefon prineti uređaju za plaćanje i tako obaviti transakciju.

\subsection{Mobilni keš}

Mobilni keš predstavlja način punjenja mobilnih telefona "kešom" najčešće pomoću smart kartica. Koncept je još uvek u eksperimentalnoj fazi i još uvek nema jedinstvenog procesa koji bi se nametnuo kao standard u ovoj oblasti.

\section{M-KOMERC-SIGURNOST}

Sigurnost je jedan od najvažnijih zahteva mobilnog biznisa. Na primer kod finansijskih trans- 
akcija korisnici imaju malo poverenja u bezbednost aplikacija. Mogućnosti za presretanje poruke a samim tim i njeno neovlašćeno korišćenje na ovom modelu su brojne. Mesta za presretanje su komunikacija između gateway-a i web servera i između gatewaya i WAP telefona. Načini na koji se treća lica mogu uključiti u komunikaciju su:

Prisluškivanje (eavesdropping). Podaci ostaju netaknuti, ali je povređena privatnost pošiljaoca odnosno primaoca. Npr. neko može saznati tuđi broj kreditne kartice.

Neovlašteno menjanje (tampering). Podaci se promene delimično ili u potpunosti, a zatim se šalju predviđenom primaocu. Npr. neko može promeniti nečiju porudžbinu robe ili promeniti sadržaj elektronske pošte.

Imitiranje (impersonation). Podaci se preusmeruju osobi koja imitira predviđenog primaoca. Imitiranje se može javiti u dva oblika:

- Prevara (spoofing). Osoba se može pretvarati da je neko drugi. Npr. osoba se može identifikovati tako da koristi tuđi mail.

- Lažno predstavljanje (misrepresentation). Osoba ili organizacija se mogu predstaviti kao neko ili nešto što u stvarnosti nisu. Npr. www.prodaja.co.yu se može predstaviti i izgledati kao da je on-line prodavaonica, a zapravo jedino što radi je uzimanje brojeva kreditnih kartica, a nikada ne dostavlja robu.

Efikasan, za sada standardni način zaštite podataka na Internetu je primena tehnike sastav javnih ključeva (PKI) zasnovan na kriptrografiji javnog ključa koja ostvaruje sledeće zadatke:

- Šifrovanje i dešifrovanje (encryption and decryption) dozvoljavaju dvoma učesnicima u komunikaciji da sakriju sadaržaj koji šalju jedan drugome. Pošiljalac šifruje podatke pre nego ih pošalje, dok ih primalac dešifruje nakon što ih primi. Dok podaci putuju kroz mrežu nerazumljivi su potencijalnom slušaocu (osobi koja ima pristup posredničkom računaru),

- Detekcija neovlašćenog pristupa (tamper detection) omogućuje primaocu da proveri jesu li podaci prilikom svog puta kroz mrežu bili promenjeni. Svaki pokušaj promene sadržaja ili zamene novim biće otkriven,

- Provera verodostojnosti (authentication) dozvoljava primaocu podataka da proveri verodostojnost njihovog izvora, odnosno da potvrdi identitet pošiljaoca,

- Sprečavanje nepriznavanja (nonrepudiation) onemogućuje pošiljaoca podataka da kasnije tvrdi kako te podatke nije poslao.

Naravno tu postoji i treći element (osim ova dva ključa), a to je digitalni sertifiakat koji je potpisan od treće strane koja je autorizovana za izdavanje sertifikata. Primer jedne tranakcije baziran na PKI tehnologiji (slika 3.):

Pošiljalac kriptuje svoje poverljive podatke pomoću javnog ključa primalaca. Bitna napomena je da se tajni ključ nikad ne prenosi putem Interneta za vreme transakcije.

Primalac poruke koristi svoj tajni ključ koji mu omogućuje da pročita kriptovanu poruku. Poruka može sadržati finansijska uputstva ili druge poverljive informacije.

Ukoliko neko presretne poruku, on neće moći da je pročita pošto se ona može dekriptovati samo pomoću tajnog ključa koji se nalazi kod primaoca. Taj mehanizam za sada predstavlja sistem sigurnog prenosa podataka (slika 4.)

Da bi se osigurali da poruka neće biti menjana u toku prenosa ona može da se ,digitalno potpiše“". Digitalan potpis osigurava da podaci nisu menjani u toku prenosa pošto je on vezan za podatke i svaka promena na njima bi se otkrila. Ovakav metod zaštite drastično smanjuje mogućnosti za hakerske upade i povredu sigurnosti transakcije. Enkripcija, ustvari, predstavlja „,trgovinu“ između bezbednosti i brzine izvršavanja transakcija. Brzina kriptovanja zavisi od mobilnog uređaja, uobičajeno je da se vrši sa 32-bitnim procesorima. 


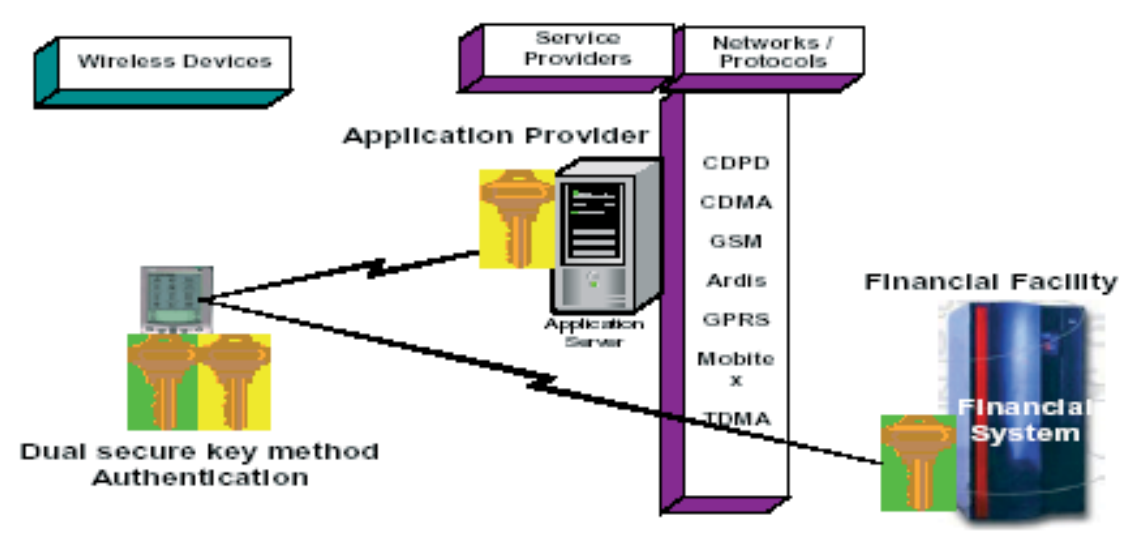

Slika 3.: Sistem zaštite pomoću šifriranja

\section{M-COMMERCE -SCG}

Razvoj telekomunikacionh sistema u našoj zemlji nije na zadovoljavajućem nivou. Tržište mobilne telefonije je relativno siromašno i nepravilno fragmentirano. Dok većina svetskih operatora mobilne telefonije najveće prihode ostvaruje od omladine starosti do 18 godina, studenata i zaposlenih do 30 godina starosti, u našoj zemlji najveće prihode generišu zaposleni starosti od 30 do 50 godina i pravna lica (firme). Takođe, iako domaći provajderi mobilne telefonije, ukazuju na niske ARPU (Average Revenue per User) koefici- jenta, jasno je da domaće tržište može prihvatiti jednog možda i dva nova operatora, koji bi dobili licence u skladu sa budućom zakonskom regulativom. Potrebno je da se definiše prava strategija i da se stvore prava partnerstva koja će voditi uspehu u m-Commerce-u. U mnogim tržištima, kao i onim na Internetu, u ranoj fazi nisu postojali standardni proizvodi i kompanije su morale da ih razvijaju interno, i kao takve ih predstavljaju tržištu. Sve ove kompanije su paralelno sa svojim aplikacijama i servisima, razvijale i iskustvo i navike korisnika. Na tržištima brojnih Internet servisa, pioniri su uspeli da i do danas zadrže

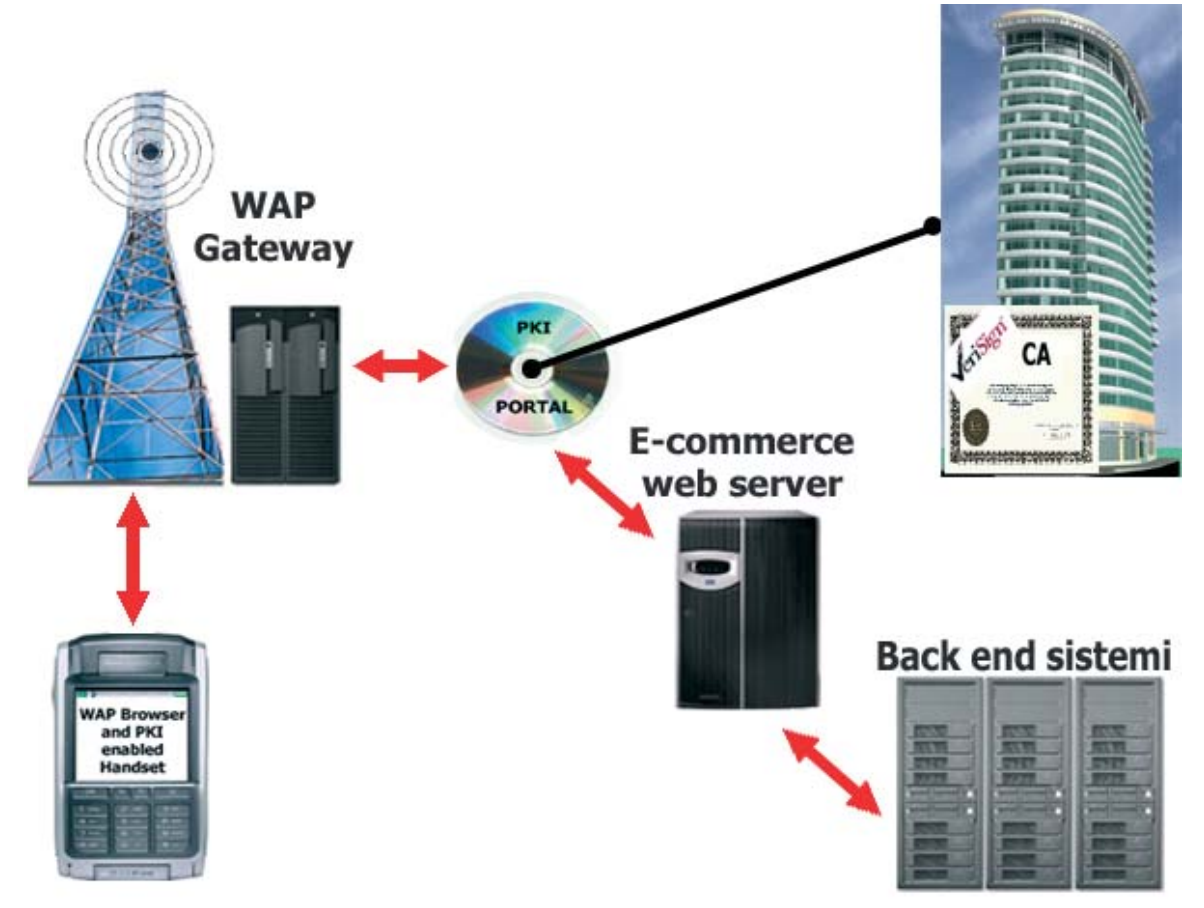

S1. 4. : Sistem sigurnog prenosa podataka 
lidersku poziciju. Primeri su brojni, a među najpoznatiji su Yahoo, Amazon.com, Aol. Velika je verovatnoća da će se ovaj scenario ponoviti i sa $m$-Commerce servisima. Nema razloga da ne verujemo da će tako biti i u našoj zemlji.

Već sada postoje brojni načini za razvoj mCommerce servisa. Kao jedan od najvažnijih i najpristupačnijih, nameće se WAP tehnologija. Ipak operateri mobilne telefonije i Internet provajderi u SCG su prosto prešli preko ove tehnologije, tako da se na prste mogu izbrojati oni koji nude podršku WAP aplikacijama.

Mobilni operatori imaju mogućnost i razvoja prelaznih rešenja u m-Commerce segmentu. Jedno od takvih rešenja su bankarski sistemi za transakciono povezivanje mobilnih telefona $\mathrm{i}$ POS terminala. S obzirom da u našoj zemlji već postoje POS sistemi, moguća je nadogradanja za primenu u ovim specifičnim aplikacijama. Iskustva sa ovakvim m-Commerce rešenjima u svetu su vrlo pozitivna, jer su na taj način otklonjeni i problemi sigurnosti i privatnosti korisnika, uz jednostavnost i brzinu usluga.

\section{ZAKLJUČAK}

U ovom radu razmatrano je na koji način Internet može da se iskoristi u m-commerce svrhe. Sledi zaključak da mobilni internet predstavlja jedan od najefikasnijih načina za uspostavljanje čvrstih veza sa korisnicima i povećanje prihoda kompanijama. Za turbulentno okruženje kakvo danas postoji u mobilnom svetu potpuni je izazov uspostaljanje prave strategije. Aplikacije za mobilni biznis moraju biti kompatibilne sa standardnim aplikacijama koje koriste neke finansijske institucije ili kompanije u svom postojećem informacionom sistemu. Mobilna tehnologija je uhvatila zamah i nastavlja sa svojim razvojem i rastom postajući pristupačnija, sve moćnija i funkcionalnija.

S obzirom da je u našoj zemlji i elektronska trgovina u povoju, najverovatnije je da će i razvoj
m-Commerce tržišta i usluga kasniti u odnosu na druge zemlje. Što se tiče odnosa broja korisnika računara i mobilnih telefona u našoj zemlji je oko 1:10, što može biti motiv da se m-Commerce segmentu elektronske trgovine posveti posebna pažnja.

Vreme i tehnologija ne čekaju nikog. Ako se želi ostati u bespoštednoj trci u konkurentskom okruženju, sve kompanije i finansijske institucije moraju da prepoznaju jedinstvene kvalitete i potencijale mobilnih aplikacija, odluče kako da ih integrišu u svoje informacione sisteme i ostvare sopstvena mobilna rešenja. Samo se tako opstaje na tržištu i stvara preduslov za liderstvo.

\section{RESUME \\ Mobile E-Commerce}

Mobile users will increasingly demand access to Mobile Commerce Service. Therefore existing technologies have to be investigated if they can be adapted to the mobile enviroment. This paper presents an overview on the state of the art of $\mathrm{m}$ commerce as phenomenon of today. It is introduced as a general concept covering any business transaction executed electronical between at least two parties whereas at least one of these parties is mobile. Being mobile implies that the mobile party uses wireless transmission medium at least on the first link for the communication with the other partie. M-commerce services should to be able to integrate different types of information and manage to secure the speed security and privacy of the transactions.

\section{BIBLIOGRAFIJA}

1. Mobilocity White Paper, Understanding the Fundamentals of m-Commerce, 2000.

2. Logica White Paper, Mobile Banking : The future is on the move, London, 2001.

3. W. W. Jeang : M-Commerce : E-commerce With a Twist, Low.com, 2001. 
4. Durlacher Research White Paper, Mobile Commerce Report, London, 2000.

5. E, Jensen, M-Payments Meet Point-of Sale, $M$ Business Magazine, 2001.

6. Mr Trninić Damir, Bluetooth tehnologija, poslediplomske studije, Saobraćajni fakultet, Beograd, 1998.

7. Quentin Mendoza, Staff Writer, This season for m-commerce, Anywhereyougo.com 2000.

8. Risto Perttunen, McKinsey \& Co., Global wireless m-commerce practice leader, 2004.

9. Nikki Swartz, Hot \& Cold M-Commerce Opportunities, Wireless Review TelecomClick,Mar 19 2001.

10. Chris Goldman, Staff Writer, The M-Commerce Horizont, Wireless Review, Jul 1, 2000.

. Mobilo Financilal Servises, Mobilo City. net 2000

. Iyotsna Mishra, Grant Gustafson,Mobile Commerce-Strategic Implications for Banks, Artur D Little 2001

. www.wapforum.org

. Rod Ghani, The Future of WirelessBanking, IBM Global Servises 2001

. Quentin Mendoza, Staff Writer, This season for mcommerce, Anywhereyougo.com 2000 